\title{
Feasibility Study on Long-Term Continuous Ethanol Production from Cassava Supernatant by Immobilized Yeast Cells in Packed Bed Reactor
}

\author{
Qingguo Liu', Nan Zhao', Yanan Zou' ${ }^{1}$, Hanjie Ying ${ }^{2}$, Dong Liu' ${ }^{2}$, and Yong Chen ${ }^{2 *}$ \\ ${ }^{1}$ Nanjing Institute of White-Biotech Co. Ltd., Medicine valley Avenue 11, Nanjing 210032, P.R. China \\ ${ }^{2}$ College of Biotechnology and Pharmaceutical Engineering, Nanjing Tech University, Xin mofan Road 5, Nanjing \\ 210009, P.R. China
}

\begin{abstract}
In this study, yeast cell immobilization was carried out in a packed bed reactor (PBR) to investigate the effects of the volumetric capacity of carriers as well as the different fermentation modes on fuel ethanol production. An optimal volumetric capacity of $10 \mathrm{~g} / \mathrm{l}$ was found to obtain a high cell concentration. The productivity of immobilized cell fermentation was $16 \%$ higher than that of suspended-cell fermentation in batch and it reached a higher value of $4.28 \mathrm{~g} / \mathrm{l} / \mathrm{h}$ in repeated batches. Additionally, using this method, the ethanol yield (95.88\%) was found to be higher than that of other tested methods due to low concentrations of residual sugars and free cells. Continuous ethanol production using four bioreactors showed a higher productivity $(9.57 \mathrm{~g} / \mathrm{l} / \mathrm{h})$ and yield $(96.96 \%)$ with an ethanol concentration of $104.65 \mathrm{~g} / \mathrm{l}$ obtained from $219.42 \mathrm{~g} / \mathrm{l}$ of initial total sugar at a dilution rate of $0.092 \mathrm{~h}^{-1}$. Furthermore, we reversed the substrate-feed flow directions in the in-series bioreactors to keep the cells at their highest activity and to extend the length of continuous fermentation. Our study demonstrates an effective method of ethanol production with a new immobilized approach, and that by switching the flow directions, traditional continuous fermentation can be greatly improved, which could have practical and broad implications in industrial applications.
\end{abstract}

Keywords: Cassava supernatant yeast, ethanol, packed bed reactor, continuous fermentation, alternate control strategy

Received: August 8, 2019 Accepted: September 15, 2019

First published online: September 30, 2019

* Corresponding author Phone: +86-25-86990001 Fax: +86-25-5813938 E-mail: chenyong1982@njtech. edu.cn

pISSN 1017-7825 elSSN 1738-8872

Copyright(C) 2020 by The Korean Society for Microbiology and Biotechnology

\section{Introduction}

The world is facing an energy crisis today as fossil fuels and other non-renewable energy sources are being exhausted [1]. Looking for new alternative energy sources has become the focus of energy research. Bioethanol is not only a renewable fuel from different kinds of renewable feedstock such as sugar cane, corn, wheat, cassava, and cellulose biomass [2], but can also be mixed with gasoline to be used in any proportion to alleviate the pressure from the oil demand. In particular, cassava-based bioethanol production is being carried out mainly in China and Southeast Asia as an effective method to reduce greenhouse gas emissions, promote energy security, and avoid a food crisis [3].

In the ethanol production process with cassava powder, the fermented liquid viscosity is too high and impacts the continuous flow of material, which adversely affects the mixing and hence, the control of the mash temperature. Additionally, impurities in the cassava medium can place wear on equipment, cause pipeline and equipment jams, and lead to cleaning difficulties and bacterial contamination. Ethanol production using cassava supernatant not only overcomes the deficiencies of traditional fermentation but can also improve production capacity and increase the productivity of fermentation. This technology reduces energy consumption by improving the distillation efficiency and decreases the cost of sewage treatment by reducing the chemical oxygen demand in the fermented liquor. Furthermore, this technique can be applied to continuous ethanol production combined with immobilized cell fermentation. Many researchers have previously investigated continuous ethanol production and found that alcohol fermentation by immobilized yeast is superior to fermentation by free yeast. Najafpour et al. [4] reported that bioethanol production by immobilized cells within alginate beads provided higher productivity than that of free cells in a batch system. Furthermore, Bangrak et al. [5] found ethanol productivity in continuous culture was 6-8-fold higher than that in batch culture. Other studies have shown that high density fermenters improve both ethanol yield and biomass recovery [6-8].

Many researchers have also focused on improving the stability of continuous production of bioethanol by a 
number of methods such as cell recycling $[9,10]$, fermentation coupling with separation $[11,12]$, optimizing fermentation conditions [13, 14], and different fermenter designs [7]. However, these efforts faced limitations such as materials degradation, low mechanical strength and poor mass transfer, problems that have been often observed when using immobilization fermentation. Previously, immobilized yeast cells adsorbed onto modified fibrous matrix carriers were successfully developed for repeated batch ethanol productions in a $700 \mathrm{~L}$ fermenter. This method had many advantages including low cost, high porosity, high specific surface area, good adsorption efficacy, strong stability, and enhanced productivity [15].

In this study, we used a new type of medium in the yeast cell immobilization and mainly focused on the feasibility of continuous ethanol production using cassava supernatant. In order to improve the productivity and keep a long-term stable fermentation, different dilution rates and switch controls were investigated.

\section{Materials and Methods}

Microorganism and Culture Medium

Saccharomyces cerevisiae 1308 was provided by the Tian-Guan Group (China). The strain was stored and cultured as previously described [15]. The seed culture medium contained the following: glucose $(100 \mathrm{~g} / \mathrm{l})$, peptone $(20 \mathrm{~g} / \mathrm{l})$, and yeast extract $(10 \mathrm{~g} / \mathrm{l})$. Cassava chips with a starch content of approximately $72.5 \%$ were obtained from the Tian-Guan Group. Cassava powder was made by grinding the chips with a hammer mill and screening out the larger particles using a $1-\mathrm{mm}$ screen. The cassava was mixed with tap water at a mass ratio of 1:2.6 and $\mathrm{pH}$ was adjusted to 5.5-6.0 with $\mathrm{NaOH}$ solution. Following this, $\alpha$-amylase ( $16 \mathrm{U} / \mathrm{g}$ of starch) was added. The mixture was then hydrolyzed by heating to $86^{\circ} \mathrm{C}$ for $2 \mathrm{~h}$. Finally, the hydrolysate was filtered by a frame filter press in preparation for continuous ethanol production.

\section{Cell Immobilization}

Cell immobilization was carried out in a packed bed reactor (PBR) that included two main parts: immobilized fillers and a $20 \mathrm{~L}$ recirculation tank, with a diameter of $14 \mathrm{~cm}$ and a height of $33 \mathrm{~cm}$. Each immobilized filler consisted of a porous hollow ball with a diameter of $2.5 \mathrm{~cm}$ and a pore diameter of $0.8 \mathrm{~cm}$ as well as a sheet cotton fiber $\left(2.5 \mathrm{~cm}\right.$ diameter). The PBR was sterilized for $15 \mathrm{~min}$ at $105^{\circ} \mathrm{C}$.

The initial seed culture was carried out in four $5 \mathrm{~L}$ shake flasks with $2.5 \mathrm{~L}$ of medium by culturing at $160 \mathrm{rpm}$ and $30^{\circ} \mathrm{C}$. For the second seed culture, the first seed was inoculated into a $100 \mathrm{~L}$ fermenter containing $70 \mathrm{~L}$ of seed medium, and incubated for $18 \mathrm{~h}$ at $30^{\circ} \mathrm{C}$ and $0.15 \mathrm{~m}^{3} / \mathrm{min}$ of air flow. The second seed was then inoculated into each PBR and incubated at $30^{\circ} \mathrm{C}$ with a circulation flow rate of $25 \mathrm{~L} / \mathrm{h}$ to ensure immobilization. After $30 \mathrm{~h}, 10 \%$ cassava hydrolysate was added.

\section{Batch and Repeated-Batch Fermentation}

For free cell fermentation, $1.5 \mathrm{~L}$ of seed and $14.5 \mathrm{~L}$ of fermentation broth $(\mathrm{pH} 4.4)$ were added to a $20 \mathrm{~L}$ PBR. Glucoamylase (200 U/g of starch) was then added. The fermenter content was recirculated at $30 \mathrm{~L} / \mathrm{h}$ and its temperature was controlled at $33^{\circ} \mathrm{C}$ by a water bath. Each experiment was repeated 3 times. Repeated-batch simultaneous saccharification and fermentation (SSF) by immobilized cells was also carried out in a $20 \mathrm{~L}$ PBR after the immobilization process, where $16 \mathrm{~L}$ of the same fermentation broth was added to the reactor. The fermentation conditions were the same as those used for free cell fermentation. At the end of each batch, which was defined by the level of reducing sugar dropping below $1 \mathrm{~g} / \mathrm{l}$, the fermented broth was removed, the same amount of fresh medium was added, and the next batch was initiated. The immobilized cells were used for 6 successive batches. Samples were collected at regular intervals and analyzed for ethanol production yield and reducing sugars.

\section{Continuous Ethanol Productions}

Continuous ethanol production was carried out in a $20 \mathrm{~L}$ four-stage cascade PBR system. The fermentation broth, prepared in a substrate feeding tank, contained magnesium sulfate $(0.2 \mathrm{~g} / \mathrm{l})$ and urea $(0.2 \mathrm{~g} / \mathrm{l})$, and then $5 \mathrm{M}$ sulfuric acid was used for $\mathrm{pH}$ adjustment by a peristaltic pump. Glucoamylase $(180 \mathrm{U} / \mathrm{g})$ was pumped into the PBR with the fermentation broth and the temperature was maintained at $33^{\circ} \mathrm{C}$.

\section{Analytical Methods}

The 3,5-dinitrosalicylic acid (DNS) method as described by Miller [16] was used for reducing sugar detection. The total sugars were hydrolyzed using $6 \mathrm{M} \mathrm{HCl}$ for $2 \mathrm{~h}$ at $100^{\circ} \mathrm{C}$ and then they were analyzed using the same method [16]. Ethanol was determined by high-performance liquid chromatography (HPLC), and the concentration of free cells was determined using a blood counting chamber as previously described [15]. The ethanol yield and productivity were calculated as below:

Ethanol yield, $\mathrm{Y}(\%)=\mathrm{C}_{\mathrm{E}} /\left[\left(\mathrm{C}_{\mathrm{G} 0}-\mathrm{C}_{\mathrm{G}}\right) \times 0.511\right] \times 100 \%$

Ethanol productivity, $\mathrm{P}(\mathrm{g} / \mathrm{l} / \mathrm{h})=\mathrm{C}_{\mathrm{E}} / \mathrm{T}$

where $\mathrm{C}_{\mathrm{E}}$ indicates ethanol concentration, $\mathrm{C}_{\mathrm{G} 0}$ and $\mathrm{C}_{\mathrm{Gt}}$ indicate initial total sugar and final total sugar; $\mathrm{T}$ indicates fermentation time.

Meanwhile, $C_{R}, C_{C}$ and $D$ indicate reducing sugar concentration, cell concentration and dilution rate, respectively. 


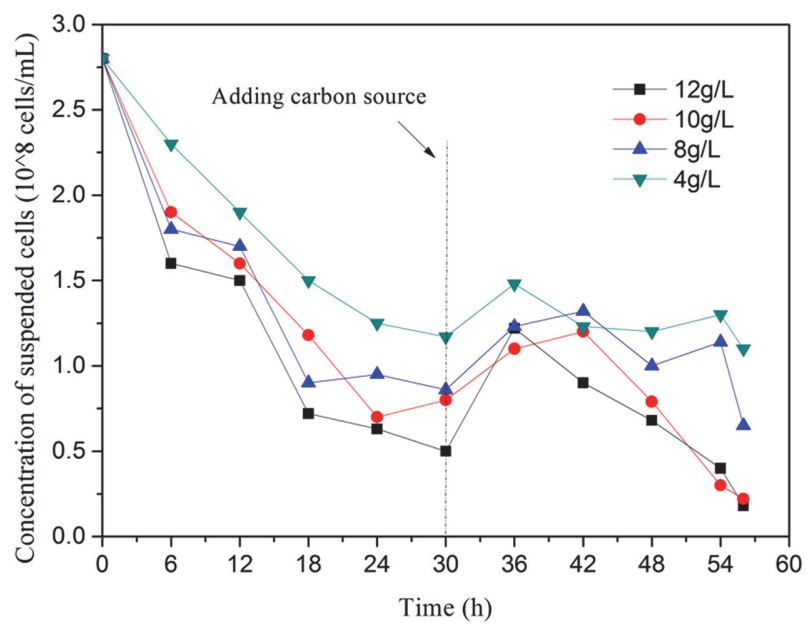

Fig. 1. Time courses of cell immobilization at the different additive amount of carriers.

\section{Scanning Electron Microscopy (SEM) and Confocal Laser Scanning Microscopy (CLSM)}

The immobilized cells on the carrier were washed twice with phosphate-buffered saline (PBS), freeze-dried using the FreeZone Freeze Dry System (Labconco Corporation, USA), and then scanned and imaged using scanning electron microscopy (SEM, model JSM-6010, JEOL Ltd., Japan).

For CLSM, the immobilized cells were washed twice with PBS and stained immediately with both FUN-1 (Molecular Probes, Inc., USA) and Alexa Fluor 488 conjugated to concanavalin A (ConA) (Molecular Probes, Inc.) as previously described [17]. FUN-1 is converted to an orange-red molecule in metabolically active cells, and ConA binds to the glucose and mannose residues of cell-wall polysaccharides, a green fluorescence. The images were captured using a Leica TCS SP5 II.

\section{Results and Discussion}

\section{Optimization of Cell Immobilization Process}

Previously, spiral wound carriers have been used to immobilize cells; however, as the liquid flowed vertically there was less contact with the carrier surface, and thus the rate of immobilization was reduced [15, 18, 19-21]. In this study, the sheet cotton fibers were packed into porous hollow balls, which increased the contact area of free cells, while also reducing the use of steel wire mesh. As seen from Fig. 1, the free cell concentration varied depending upon the adsorption time and amount of carrier used. The amount of adsorbed cells on the carriers was roughly equal to the reduced concentration of suspended cells as previously described [15]. The concentration of suspended cells in all experimental groups was found to be decreased during the initial $30 \mathrm{~h}$, with this reduction seemingly related to the different amounts of carrier added. For example, the free cell concentration decreased to $0.5 \times 10^{8}$ cell $/ \mathrm{ml}$ at $30 \mathrm{~h}$ with the addition of $12 \mathrm{~g} / \mathrm{l}$, while a slower rate of reduction was found with the addition of $4 \mathrm{~g} / \mathrm{l}$. In total, $1 \mathrm{~kg}$ of carbon source was added to each bioreactor at $30 \mathrm{~h}$. It was observed that the concentrations of free cells in all groups were increased, and this was followed by a distinct decrease after 36-42 h except for the $4 \mathrm{~g} / \mathrm{l}$ reactor. The adsorbed cells in each group (Fig. 1) were more than $3.2 \times 10^{8}$ cells $/ \mathrm{ml}, 3.0 \times 10^{8} \mathrm{cells} / \mathrm{ml}, 2.3 \times 10^{8}$ cells $/ \mathrm{ml}, 1.7 \times 10^{8}$ cells $/ \mathrm{ml}$, respectively. When considering the adsorption capacity, mass-transfer efficiency and economic factors, we chose $10 \mathrm{~g} / \mathrm{l}$ as the amount added for all later experiments, from which we observed the yeast cell adsorption and growth in the process of immobilization (Fig. 2). There was an obvious adsorbed state for the yeast cells on the carrier surface (Fig. 2A), and cells gathered on the carrier in groups one by one (Fig. 2B). After $24 \mathrm{~h}$, a biofilm formed on the surface (Figs. 2C and 2D), protecting the cells from any harmful chemicals [22, 23].

\section{Batch and Repeated Batch Fermentation}

To assess the value of the application of immobilized yeast cells, we compared it to traditional fermentation technology (Fig. 3A). We found that the consumption rates of residual total sugar and reducing sugars, as well as the production rate of ethanol in immobilized yeast fermentation (Fig. 3B) were faster than those in the free cell
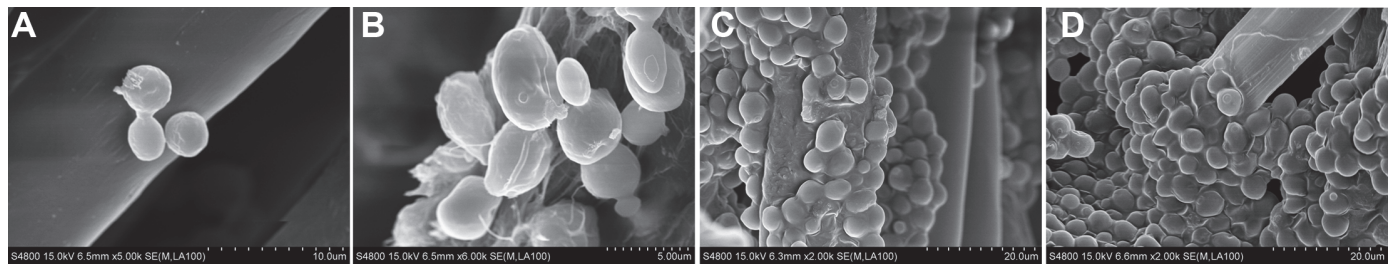

Fig. 2. Scanning electron micrograph of the process of yeast cell adsorption. (A) Adsorption for $2 \mathrm{~h}$, (B) adsorption for $12 \mathrm{~h},(\mathbf{C})$ adsorption for $24 \mathrm{~h},(\mathbf{D})$ adsorption for $48 \mathrm{~h}$. 

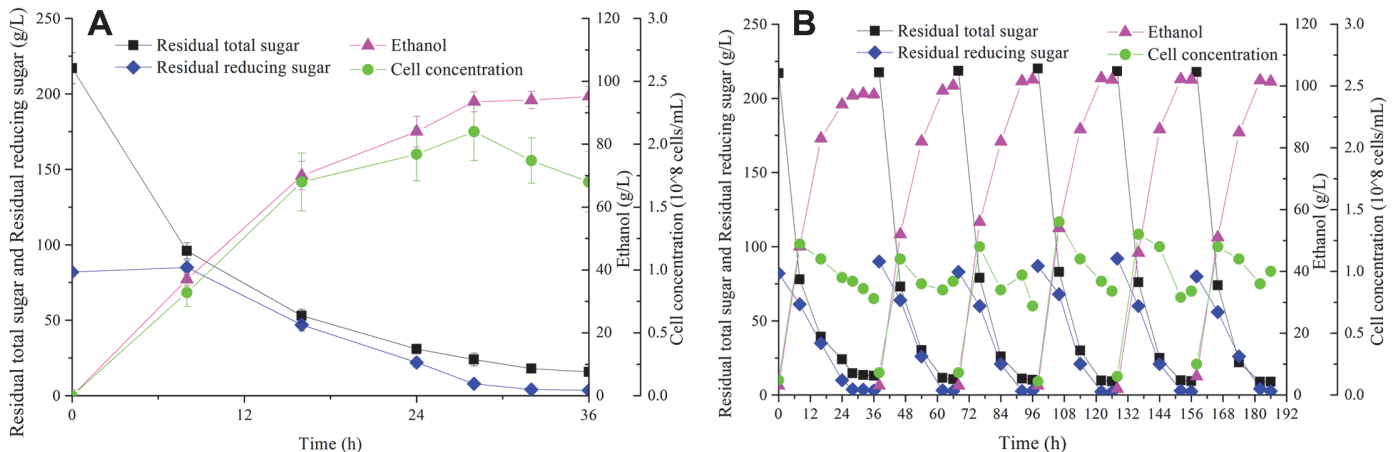

Fig. 3. Profiles of residual total sugar, residual reducing sugar, ethanol production, and cell concentration during ethanol fermentation by free and immobilized yeasts. (A) Free cell fermentationm (B) Immobilized cell fermentation.

fermentation, especially in the early stage. As expected, the free cell concentration in immobilized cell fermentation was found to be significantly lower than that of the immobilized cell fermentation. Furthermore, in the second batch of immobilized cells the rate of fermentation was found to be faster than that of the first batch, and it reached a steady state producing $102.65 \mathrm{~g} / \mathrm{l}$ of ethanol. This is slightly different from previous studies [15]. In the first 2 cycles with unfiltered cassava hydrolysate, the rates of fermentation were fast due to small amounts of scum adsorbed onto the surface of the carrier. Therefore, in this study we noted that there was minimal scum effect on the cells on the carrier surface, thus leading to a higher fermentation rate. Additionally, there was an increased amount of cell adsorption and a balanced state was achieved in the later four batches.

The productivity of immobilized cell fermentation was $16 \%$ higher than that of suspended-cell fermentation in batch and reached a higher value of $4.28 \mathrm{~g} / \mathrm{l} / \mathrm{h}$ in repeated batches (Table 1). The ethanol yield in the first batch, with the immobilized cells, was similar to that of the free cell fermentation, while in later batches, the mean yield from immobilized cell fermentation was higher than that obtained from free cell fermentation, most likely due to the lower concentrations of residual total sugars and free cells. This result can be explained by the fact that the immobilized yeast cells in the production of ethanol may overcome the product inhibition as previously reported [24] and that the sugar can be consumed more completely, resulting in improved ethanol concentration.

In the process of yeast cell adsorption, it was found that a biofilm formed on the surface of the carrier. Many studies have shown that a biofilm has basic components, such as proteins, DNA/RNA, lipids, and extracellular polysaccharides $[25,26]$. The biofilm was stained with a ConA probe, which was able to react with polysaccharides, and a FUN-1 probe, which reacted with the cytoplasm (Fig. 4). The results showed that the

Table 1. Influence of different fermentation modes on fuel ethanol production.

\begin{tabular}{cccc}
\hline \multirow{2}{*}{ Parameter } & Free cell fermentation & \multicolumn{2}{c}{ Immobilized cell fermentation } \\
\cline { 3 - 4 } & & First batch & Repeat batches \\
\hline $\mathrm{C}_{\mathrm{G} 0}(\mathrm{~g} / \mathrm{l})$ & 217.62 & 217.62 & 218.91 \\
$\mathrm{~T}(\mathrm{~h})$ & 32 & 28 & 24 \\
$\mathrm{C}_{\mathrm{Gt}}(\mathrm{g} / \mathrm{l})$ & 15.51 & 12.22 & 9.40 \\
$\mathrm{C}_{\mathrm{E}}(\mathrm{g} / \mathrm{l})$ & 95.80 & 97.52 & 102.65 \\
$\mathrm{C}_{\mathrm{R}}(\mathrm{g} / \mathrm{l})$ & 3.8 & 2.8 & 2.3 \\
$\mathrm{Cc}\left(10^{8} \mathrm{cells} / \mathrm{ml}\right)$ & 1.88 & 0.84 & 0.90 \\
$\mathrm{pH}$ & 3.85 & 3.93 & 3.95 \\
$\mathrm{P}(\mathrm{g} / \mathrm{l} / \mathrm{h})$ & 3.00 & 3.48 & 4.28 \\
$\mathrm{Y}(\%)$ & 92.76 & 92.91 & 95.88
\end{tabular}

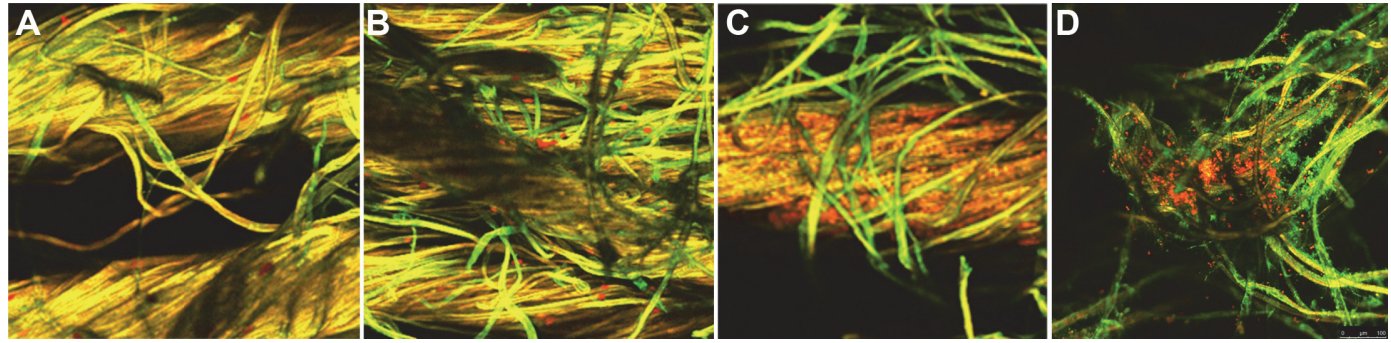

Fig. 4. Confocal laser scanning microscopy of immobilized cells during the immobilization and fermentation processes. (A) Immobilization for 2 days, (B) fermentation for 2 days, (C) fermentation for 5 days, (D) fermentation for 10 days. 

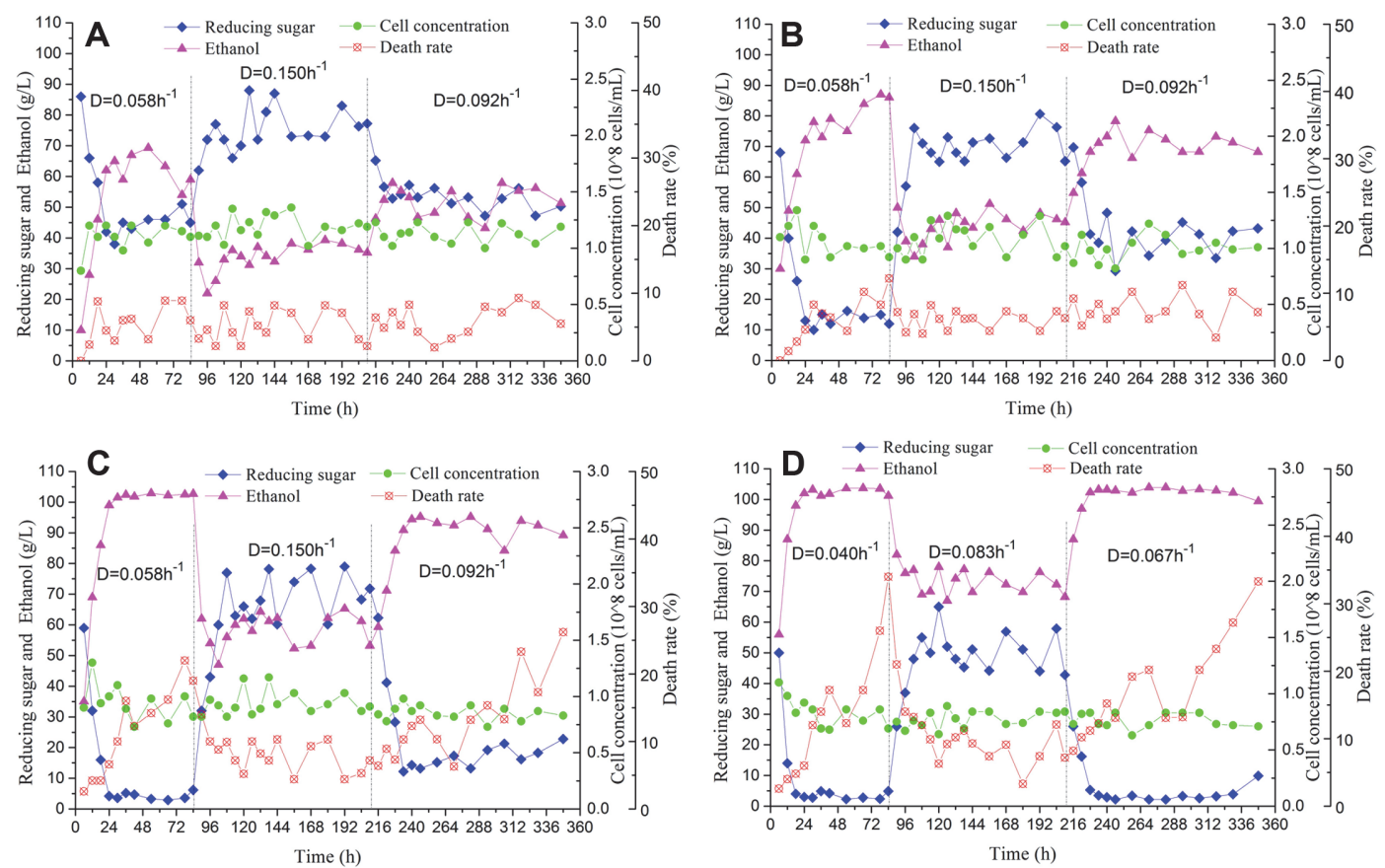

Fig. 5. Kinetics of continuous ethanol fermentation at different dilution rates. (A) $1^{\text {st }}$ bioreactor, (B) $2^{\text {nd }}$ bioreactor, (C) $3^{\text {rd }}$ bioreactor, (D) $4^{\text {th }}$ bioreactor.

biofilm was mostly made up of the cells and this was followed by extracellular polysaccharide composition (Fig. 4, green). With longer incubation times, the proportion of extracellular polysaccharide increased, especially after 10 days of fermentation, in accordance with previous studies [27-29]. We speculate that extracellular polysaccharide is involved in the synthesis of glycoproteins, which are known important functional proteins [30]. Therefore, it can be hypothesized that the ethanol tolerance of the immobilized cells was enhanced due to the extracellular polysaccharide of the biofilm.

\section{Continuous Ethanol Production and Effects of the Dilution Rate}

After the repeated batches were finished, continuous ethanol production using immobilized cells was carried out in a series-wound bioreactor (Fig. 5). The concentrations of the substrate, ethanol, and free cells as well as the cellular death rate were found to vary as the dilution rates were varied. The consumption rate of sugar in all the bioreactors was fast in the early fermentation stage and achieved a dynamic balance after $28 \mathrm{~h}$ at a dilution rate of $0.058 \mathrm{~h}^{-1}$. In the $3^{\text {rd }}$ and $4^{\text {th }}$ bioreactors, the sugar was almost completely consumed and the ethanol production reached $104.32 \mathrm{~g} / \mathrm{l}$ and $104.86 \mathrm{~g} / \mathrm{l}$, respectively. When the fermentation was carried out for $72 \mathrm{~h}$, the cellular death rate of the free cells in the $3^{\text {rd }}$ and $4^{\text {th }}$ bioreactors was raised to a high level. In particular, in the $4^{\text {th }}$ bioreactor the death rate reached $30 \%$, most likely due to the lack of nutrition, a limited carbon source, and ethanol inhibition. Therefore, the dilution rate was adjusted from $0.058 \mathrm{~h}^{-1}$ to $0.150 \mathrm{~h}^{-1}$. The concentrations of free cells in the other three fermenters showed little improvement, due to more sugar being fed. The residual sugar concentration in each fermenter showed an obvious increase and reached a steady state with other parameters after approximately $108 \mathrm{~h}$. The concentration of sugar in the $4^{\text {th }}$ bioreactor remained at a high level of approximately $59.12 \mathrm{~g} / \mathrm{l}$ and the ethanol production decreased to $74.51 \mathrm{~g} / \mathrm{l}$ (Table 2). When the fermentation was run for $216 \mathrm{~h}$, the dilution rate was adjusted to $0.092 \mathrm{~h}^{-1}$ from $0.150 \mathrm{~h}^{-1}$ and it was observed that the sugar concentration declined rapidly, with production increases only seen in the later cycles. The ethanol concentration increased to $104.65 \mathrm{~g} / \mathrm{l}$ again in the last bioreactor, whereas in the third bioreactor it reached approximately $93.56 \mathrm{~g} / \mathrm{l}$, due to the extra unconsumed sugar. The activity of the free cells in all bioreactors remained at a high level due to sufficient amounts of substrate at a dilution rate of $0.092 \mathrm{~h}^{-1}$, and thus led to a longer term production of ethanol compared to the dilution rate of $0.058 \mathrm{~h}^{-1}$.

Table 2. Influence of different dilution rates on ethanol production of the fourth fermentation tank.

\begin{tabular}{cccccccc}
\hline $\begin{array}{c}\mathrm{D} \\
\mathrm{h}^{-1}\end{array}$ & $\begin{array}{c}\mathrm{C}_{\mathrm{G} 0}{ }^{\mathrm{a}} \\
\mathrm{g} / \mathrm{l}\end{array}$ & $\begin{array}{c}\mathrm{C}_{\mathrm{Gt}} \\
\mathrm{g} / \mathrm{l}\end{array}$ & $\begin{array}{c}\mathrm{C}_{\mathrm{R}} \\
\mathrm{g} / \mathrm{l}\end{array}$ & $\begin{array}{c}\mathrm{C}_{\mathrm{C}} \\
10^{8} \mathrm{cells} / \mathrm{ml}\end{array}$ & $\begin{array}{c}\mathrm{C}_{\mathrm{E}} \\
\mathrm{g} / \mathrm{l}\end{array}$ & $\begin{array}{c}\mathrm{P} \\
\mathrm{g} / \mathrm{l} / \mathrm{h}\end{array}$ & $\begin{array}{c}\mathrm{Y} \\
\%\end{array}$ \\
\hline 0.058 & 218.00 & 7.81 & 2.60 & 0.80 & 104.86 & 6.08 & 97.63 \\
0.150 & 217.13 & 59.12 & 51.22 & 0.92 & 74.51 & 11.18 & 92.29 \\
0.092 & 219.42 & 8.20 & 2.83 & 0.74 & 104.65 & 9.57 & 96.96 \\
\hline
\end{tabular}

${ }^{\mathrm{a}} \mathrm{C}_{\mathrm{G} 0}$ : The mean value of sugar concentration of feedstock. 

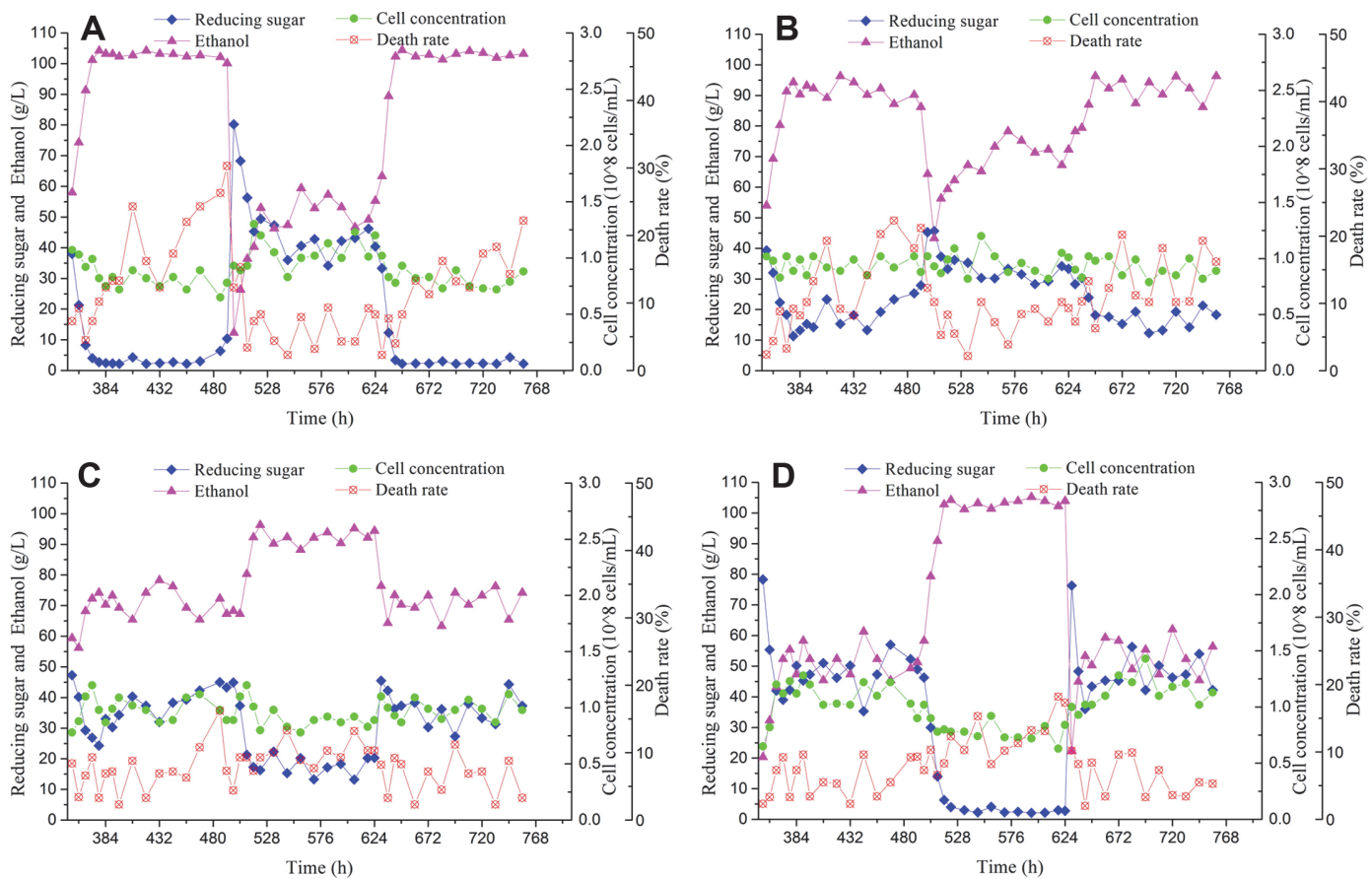

Fig. 6. Kinetics of continuous ethanol fermentation at different switch modes. (A) $1^{\text {st }}$ bioreactor, $(B) 2^{\text {nd }}$ bioreactor, (C) $3^{\text {rd }}$ bioreactor, (D) $4^{\text {th }}$ bioreactor.

The productivity of continuous ethanol production was estimated based on time course data in the steady state as seen in Table 2 . The ethanol productivity $(11.18 \mathrm{~g} / \mathrm{l} / \mathrm{h})$ increased as the dilution rate increased from 0.058 to $0.150 \mathrm{~h}^{-1}$, which is in agreement with previous studies [19,31,32]. This phenomenon may be explained by the mass transfer being enhanced and the cell activity improved by the lower ethanol concentration as the dilution rate increased [33-35]. In addition, the dissolved oxygen in the fermentation broth was increased from the feed pump with the higher dilution rate, which relieved the inhibition by ethanol $[36,37]$. Equivalently, the ethanol productivity decreased to $9.57 \mathrm{~g} / \mathrm{l} / \mathrm{h}$ when the dilution rate was reduced to $0.092 \mathrm{~h}^{-1}$. Generally, in terms of ethanol yield, a lower dilution rate gave a higher yield owing to a more complete fermentation. The maximum ethanol yield obtained was $97.63 \%$ at a dilution rate of $0.058 \mathrm{~h}^{-1}$. However, in considering the sustainability of the fermentation and production yield, we kept the dilution rate at $0.092 \mathrm{~h}^{-1}$ for later experiments.

\section{Effects of Control Strategy}

Despite continuous ethanol production enhancing the productivity and yield, questions surrounding the sustainability and stability of the fermentation still exist, limiting its application. Long-term cultures with little nutrition and production inhibition, in the last bioreactor, not only caused the decline of yeast cell activity, but also increased the risk of bacterial infection. To solve this problem, some people have improved the aeration rate to maintain the activity of the strain, while others have supplemented nutrition $[37,38]$. In this study, we reversed substrate-feed flow directions in the bioreactors in-series to maintain a high cell activity and extend the time of continuous fermentation.

At $348 \mathrm{~h}$, we reversed the flow direction, from the fourth to the first, due to high cellular death rates (> 30\%) (Fig. 6). The cellular activity was found to be recovered in the $4^{\text {th }}$ bioreactor when fresh fermentation broth was fed into it, and as the production increased, more sugar was consumed. For the $1^{\text {st }}$ bioreactor, the sugar concentration dropped to $10 \mathrm{~g} / \mathrm{l}$ when ethanol production reached $103.23 \mathrm{~g} / \mathrm{l}, 24 \mathrm{~h}$ after the flow was reversed. After 6 days of fermentation, the activity of the cells had declined, and the fermentation flow was reversed back. The phenomenon of fermentation was similar to that of the former (before the first switch), while the fermentation of the third switch also ran for 5-6 days in the same way (as with the first switch). The fermentation parameters in the

Table 3. Influence of different switch modes on the outlet ethanol production.

\begin{tabular}{ccccccc}
\hline Switch & $\begin{array}{c}\mathrm{C}_{\mathrm{G} 0} \\
\mathrm{~g} / \mathrm{l}\end{array}$ & $\begin{array}{c}\mathrm{C}_{\mathrm{Gt}} \\
\mathrm{g} / \mathrm{l}\end{array}$ & $\begin{array}{c}\mathrm{C}_{\mathrm{C}} \\
10^{8} \text { cells/ml }\end{array}$ & $\begin{array}{c}\mathrm{C}_{\mathrm{E}} \\
\mathrm{g} / \mathrm{l}\end{array}$ & $\begin{array}{c}\mathrm{P} \\
\mathrm{g} / \mathrm{l} / \mathrm{h}\end{array}$ & $\begin{array}{c}\mathrm{Y} \\
\%\end{array}$ \\
\hline First $^{\mathrm{a}}$ & 216.72 & 7.11 & 0.76 & 104.27 & 9.59 & 97.35 \\
Second $^{\mathrm{b}}$ & 218.25 & 8.28 & 0.72 & 103.13 & 9.49 & 96.12 \\
Third $^{\mathrm{c}}$ & 217.04 & 7.42 & 0.73 & 103.85 & 9.56 & 96.95 \\
\hline
\end{tabular}

${ }^{\mathrm{a}}$ First, $1^{\text {st }} \rightarrow 2^{\text {nd }} \rightarrow 3^{\text {rd }} \rightarrow 4^{\text {th }}$ switches to $4^{\text {th }} \rightarrow 3^{\text {rd }} \rightarrow 2^{\text {nd }} \rightarrow 1^{\text {st }}$

${ }^{\text {b }}$ Second, $4^{\text {th }} \rightarrow 3^{\text {rd }} \rightarrow 2^{\text {nd }} \rightarrow 1^{\text {st }}$ switches to $1^{\text {st }} \rightarrow 2^{\text {nd }} \rightarrow 3^{\text {rd }} \rightarrow 4^{\text {th }}$

'Third, same as the first fermentation mode. 
$2^{\text {nd }}$ and $3^{\text {rd }}$ bioreactors changed regularly with stability observed throughout the whole process with different switch modes. The parameters of the final outlet of the bioreactor in stable state can be seen in Table 3, with the sugar almost completely used up $(<10 \mathrm{~g} / \mathrm{l})$, and the ethanol production at more than $103 \mathrm{~g} / \mathrm{l}$, in each flow direction. Additionally, the ethanol productivity and ethanol yield were very stable. These results indicate that continuous fermentation using switch modes can be conducted with long-term stability.

\section{Feasibility of Continuous Ethanol Production}

In this study, we used sheet cotton fibers packed in porous hollow balls as immobilized carriers. This immobilization increases the contact area for free cells and improves the adsorption of cells, ensuring efficient continuous ethanol production. In addition, it also avoids the use of steel wire mesh, which reduces the cost of production. The data generated in this study for continuous ethanol production with high cell density (Fig. 1) showed a higher productivity $(9.57 \mathrm{~g} / \mathrm{l} / \mathrm{h})$ with a dilution rate of $0.092 \mathrm{~h}^{-1}$ compared to that of traditional fermentation by free cells $(3.00 \mathrm{~g} / \mathrm{l} / \mathrm{h})$. Furthermore, the yield $(96.96 \%)$ for continuous ethanol production was $4.2 \%$ higher than that of free cell fermentation. By switching the flow direction of the bioreactors the activity of cells was enhanced throughout the whole process, thus maintaining a long-term stable fermentation without contamination. Previously, we showed that the modified carrier had stronger characteristics in acidic fermentation broth over a longer period of time (more than 30 days), and therefore, we were able to control the $\mathrm{pH}$ value (3.8), in order to overcome contamination problems, a major barrier for continuous ethanol production. In summary, the application of continuous ethanol production using immobilized cells in PBRs is feasible for industrial production.

In this study, a new type of immobilized medium with high strength, great adsorption, and a perfect mass transfer was used as a cell immobilized carrier. An optimal carrier amount of $10 \mathrm{~g} / \mathrm{l}$ was shown to obtain a high cell concentration $\left(3.0 \times 10^{8} \mathrm{cells} / \mathrm{ml}\right)$, and a biofilm formed on the surface, increasing the ethanol tolerance due to the presence of extracellular polysaccharide. In batch fermentation, the ethanol yield using immobilized cells was similar to that obtained by free cell fermentation, but the productivity was $16 \%$ higher and reached a higher value of $4.28 \mathrm{~g} / \mathrm{l} / \mathrm{h}$ in repeated batches. Meanwhile, the mean yield was higher than that in the suspended-cell fermentation because of the low concentrations of residual total sugar and free cells. Continuous ethanol production with four bioreactors showed a higher productivity $(9.57 \mathrm{~g} / \mathrm{l} / \mathrm{h})$ with a dilution rate of $0.092 \mathrm{~h}^{-1}$. Switching the flow direction of the bioreactors was used to improve the activity of cells and maintain a long-term stable fermentation without contamination. This study demonstrates the feasibility of this type of technology as an effective method for ethanol production. Furthermore, it highlights that by switching the control flow direction, traditional continuous fermentation can be enhanced, which has both practical and broad implications in industrial applications.

\section{Acknowledgments}

This work was supported by the National Basic Research Program of China (973, 2013CB733602), the Major Research Plan of the National Natural Science Foundation of China (21390204), the Key Program of the National Natural Science Foundation of China (21636003), the Program for Changjiang Scholars and Innovative Research Team in University (IRT_14R28), Jiangsu National Synergetic Innovation Center for Advanced Materials (SICAM), and the Priority Academic Program Development of Jiangsu Higher Education Institutions (PAPD).

\section{Conflict of Interest}

The authors have no financial conflicts of interest to declare.

\section{References}

1. Zhu SD, Wu YW, Yu ZN, Zhang X, Wang CW. 2005. Simultaneous saccharification and fermentation of microwave/alkali pre-treated rice straw to ethanol. Bioproc. Biosyst. Eng. 92: 229-225.

2. Baeyens J, Kang Q, Appels L, Dewil R, Lv YQ, Tan TW. 2015. Challenges and opportunities in improving the production of bioethanol. Prog. Energ. Combust. Sci. 47: 60-88.

3. Nguyen TH, Williams S, Paustian K. 2017. Impact of ecosystem carbon stock change on greenhouse gas emissions and carbon payback periods of cassava-based ethanol in Vietnam. Biomass Bioenerg. 100: 126-137.

4. Najafpour G, Younesi H, Syahidah K. 2004. Ethanol production in an immobilized cell reactor using Saccharomyces cerevisiae. Bioresour. Technol. 92: 251-260.

5. Bangrak P, Limtong S, Phisalaphong M. 2011. Continuous ethanol production using immobilized yeast cells entrapped in loofareinforced alginate carriers. Braz. J. Microbiol. 42: 676-684.

6. Choi GW, Kang HW, Moon SK, Chung BW. 2010. Continuous ethanol production from cassava through simultaneous saccharification and fermentation by self-flocculating yeast Saccharomyces cerevisiae CHFY0321. Appl. Biochem. Biotechnol. 160: 1517-1527.

7. Ntihuga JN, Senn T, Gschwind P, Kohlus R. 2012. Efficiency of blenke cascade system for continuous bio-ethanol fermentation. Bioresour. Technol. 123: 221-229.

8. Xu JR, He LY, Liu CG, Zhao XQ, Bai FW. 2018. Genome sequence of the self-flocculating strain Saccharomyces cerevisiae spsc01. Genome Announc. 6: 20: e00367-18.

9. Ding WW, Wu YT, Tang XY, Yuan L, Xiao ZY. 2011. Continuous ethanol fermentation in a closed circulating system using an immobilized cell coupled with PDMS membrane pervaporation. J. Chem. Technol. Biotechnol. 86: 82-87.

10. Fan S, Chen S, Tang X, Xiao Z, Deng Q, Yao P. 2015. Kinetic model of continuous ethanol fermentation in closed-circulating process with pervaporation membrane bioreactor by Saccharomyces cerevisiae. Bioresour. Technol. 177: 169-175.

11. Offeman RD, Stephenson SK, Robertson GH, Orts, WJ. 2005. Solvent extraction of ethanol from aqueous solutions. I. Screening methodology for solvents. Ind. Eng. Chem. Res. 44: 6789-6796. 
12. Chen C, Tang X, Xiao Z, Zhou Y, Jiang Y, Fu S. 2012. Ethanol fermentation kinetics in a continuous and closed-circulating fermentation system with a pervaporation membrane bioreactor. Bioresour. Technol. 114: 707-710.

13. Khongsay N, Laopaiboon L, Jaisil P, Laopaiboon P. 2012. Optimization of agitation and aeration for very high gravity ethanol fermentation from sweet sorghum juice by Saccharomyces cerevisiae using an orthogonal array design. Energies 5: 561-576.

14. Ajbar AH, Ali E. 2017. Study of advanced control of ethanol production through continuous fermentation. J. King Saud UniversityEngineering Sci. 29: 1-11.

15. Liu QG, Cheng H, Wu JL, Chen XC, Ying HJ, Zhou P, et al. 2015. Long-term production of fuel ethanol by immobilized yeast in repeated-batch simultaneous saccharification and fermentation of cassava. Energ. Fuel. 29: 185-190.

16. Miller GL. 1959. Use of dinitrosalicylic acid reagent for determination of reducing sugar. Anal. Chem. 31: 426-428.

17. Chandra J, Kuhn DM, Mukherjee PK. 2001. Biofilm formation by the fungal pathogen Candida albicans: development, architecture, and drug resistance. J. Bacteriol. 183: 5385-5394

18. Chen Y, Liu QG, Zhou T, Li B, Yao S, Li A, et al. 2013. Ethanol production by repeated batch and continuous fermentations by Saccharomyces cerevisiae immobilized in a fibrous bed bioreactor. J. Microbiol. Biotechnol. 23: 511-517.

19. Huang WC, Ramey DE, Yang ST. 2004. Continuous production of butanol by Clostridium acetobutylicum immobilized in a fibrousbed bioreactor. Appl. Biochem. Biotechnol. 115: 113-116.

20. Kilonzo P, Margaritis A, Bergougnou MA. 2009. Airlift-driven fibrous-bed bioreactor for continuous production of glucoamylase using immobilized recombinant yeast cells. J. Biotechnol. 143: 60-68.

21. Kilonzo P, Margaritis A, Bergougnou MA. 2010. Repeated-batch production of glucoamylase using recombinant Saccharomyces cerevisiae immobilized in a fibrous bed bioreactor. J. Ind. Microbiol. Biotechnol. 37: 773-783.

22. Lee KH, Choi IS, Kim YG, Yang DJ, Bae HJ. 2011. Enhanced production of bioethanol and ultrastructural characteristics of reused Saccharomyces cerevisiae immobilized calcium alginate beads. Bioresour. Technol. 102: 8191-8198.

23. Deschaine BM, Heysel AR, Lenhart BA, Murphy HA. 2018. Biofilm formation and toxin production provide a fitness advantage in mixed colonies of environmental yeast isolates. Ecol. Evol. 8: 5541-5550.

24. Nikolić S, Mojović L, Pejin D, Rakin M, Vukašinović M. 2010. Production of bioethanol from corn meal hydrolyzates by free and immobilized cells of Saccharomyces cerevisiae var. Ellipsoideus. Biomass Bioenerg. 34: 1449-1456.

25. Prouty AM, Schwesinger WH, Gunn JS. 2002. Biofilm formation and interaction with the surfaces of gallstones by Salmonella spp. Infect. Immun. 70: 2640-2649.

26. Ma Q, Wood TK. 2009. OmpA influences Escherichia coli biofilm formation by repressing cellulose production through the CpxRA two-omponent system. Environ. Microbiol. 11:2735-2746.

27. Sutherland IW. 2001. The biofilm matrix--an immobilized but dynamic microbial environment. Trends Microbiol. 9: 222-227.

28. Alfattani MA, Douglas LJ. 2006. Biofilm matrix of Candida albicans and Candida tropicalis: chemical composition and role in drug resistance. J. Med. Microbiol. 55: 999-1008.

29. Li ZJ, Chen Y, Liu D, Zhao N, Cheng H, Ren HF, et al. 2015. Involvement of glycolysis/gluconeogenesis and signaling regulatory pathways in Saccharomyces cerevisiae biofilms during fermentation. Front. Microbiol. 6: 139.

30. Moreno JG, Coi AL, Zara G, García-Martínez T, Mauricio JC, Budroni M. 2018. Study of the role of the covalently linked cell wall protein (Ccw14p) and yeast glycoprotein (Ygp1p) within biofilm formation in a flor yeast strain. FEMS Yeast Res. 18. doi. 10.1093/ femsyr/foy005.

31. Trovati J, Giordano RC, Giordano RL. 2009. Improving the performance of a continuous process for the production of ethanol from starch. Appl. Biochem. Biotechnol. 156: 506-520.

32. Moona SK, Kimb SW, Choia GW. 2012. Simultaneous saccharification and continuous fermentation of sludge-containing mash for bioethanol production by Saccharomyces cerevisiae CHFY0321. J. Biotechnol. 157: 584-589.

33. Amenaghawon NA, Okieimen CO, Ogbeide SE. 2012. Kinetic modelling of ethanol inhibition during alcohol fermentation of corn stover using Saccharomyces cerevisiae. Int. J. Appl. Eng. Res. 4: 798-803.

34. Rittmann S, Seifert A, Herwig C. 2012. Quantitative analysis of media dilution rate effects on Methanothermobacter marburgensis grown in continuous culture on $\mathrm{H}_{2}$ and $\mathrm{CO}_{2}$. Biomass Bioenerg. 36: 293-301.

35. Rattanapan A, Limtong S, Phisalaphong M. 2011. Ethanol production by repeated batch and continuous fermentations of blackstrap molasses using immobilized yeast cells on thin-shell silk cocoons. Appl. Energ. 88: 4400-440.

36. Ryu DDY, Kim YJ. 1984. Effect of air supplement on the performance of continuous ethanol production system. Biotechnol. Bioeng. 26: $12-16$.

37. Deesuth O, Laopaiboon P, Laopaiboon L. 2016. High ethanol production under optimal aeration conditions and yeast composition in a very high gravity fermentation from sweet sorghum juice by Saccharomyces cerevisiae. Ind. Crop. Prod. 92: 263-270.

38. Xu TJ, Zhao XQ, Bai FW. 2005. Continuous ethanol production using self-flocculating yeast in a cascade of fermentors. Enzyme Microb. Technol. 37: 634-640. 